\title{
Assessment of Carbon Status in Marine Protected Area of Payung Island Waters, South Sumatera Province, Indonesia
}

\author{
Anna Ida Sunaryo Purwiyanto* and Fitri Agustriani \\ Program Study of Marine Science, Faculty of Mathematical and Science, Sriwijaya University \\ Jl. Raya Palembang - Prabumulih Km. 32 Indralaya, Palembang, Sumatera Selatan 30662 Indonesia \\ Email: anna.ida3@gmail.com
}

\begin{abstract}
$\mathrm{CO}_{2}$ is a greenhouse gas that receive more attention than the other gases because the properties of carbon easily deformed and diffuseed. Changes in the concentration of $\mathrm{CO}_{2}$ in the water will impact on changes in the amount of $\mathrm{CO}_{2}$ in the atmosphere that affect sea surface temperatures. It continuously will result in a change of marine capture fisheries. Payung Island is one of the important areas in South Sumatra that acts as the provider of the fishery. This because Payung Island is located in the mouth of Musi and Telang River covered by mangrove, has a very important ecological function. However, the condition of the carbon in the waters of the Payung Island has not explored further. This elementary study is to determine status on Payung Island waters as a sink or source of $\mathrm{CO}_{2}$. The study was conducted in June until August 2015. The research stages include surface water sampling, measurement of the $\mathrm{CO}_{2}$ in the atmosphere, the analysis of the concentration of Dissolved Inorganic Carbon (DIC) and Total Alkalinity (TA), and partial pressure of carbon dioxide $\left(\mathrm{pCO}_{2}\right)$ calculation. Atmospheric $\mathrm{CO}_{2}$ were measured insitu, while the DIC and TA were analyzed using titration methods. Partial pressure of carbon dioxide (pCO2) obtained from the calculation using the software CO2Calc using data of DIC, TA, nutrients and atmospheric CO2. The results showed that the content of DIC and TA on the Payung Island waters has similar distribution pattern i.e. high in areas close to the river, and getting lower in the area which were closer to the sea. The comparisons between $\mathrm{pCO}_{2}$ atmosphere and $\mathrm{pCO}_{2}$ waters showed that Payung Island waters generally act as a carbon sink in area towards the sea but however, in the territorial waters adjacent to the river as a source of carbon.
\end{abstract}

Keywords: carbon, marine protected area, Payung Island waters

\section{Introduction}

Global warming is a result of the increase in greenhouse gases such as $\mathrm{CO}_{2}, \mathrm{NH}_{4}$ and $\mathrm{N}_{2} \mathrm{O}$. All of the gasses resulting in global temperatures rises (IPCC, 2001). Among the three gasses, $\mathrm{CO}_{2}$ gets more attention. This is because of its link with biogeochemical cycles between $\mathrm{CO}_{2}$ in the coastal areas and open sea (Takahashi et al., 2002; Borges, 2005; Borges et al., 2005). Previous research showed that coastal waters, particularly estuaries, have primary productivity rate than the open ocean waters (Chen and Borges, 2009). This makes the coast, especially estuaries was instrumental in supporting the production of fishing to support human life.

The only Marine Protected Area (MPA) that is owned by the South Sumatra Province is coastal Payung Island. Payung Island position was in the centre of the Musi River estuary and Telang River estuary. Those make this island as a trap load input of organic materials and inorganic along the both river. The island is also located not far from the village of dense residential areas, Sungsang Village (Department of Tourism, Arts, Culture, Youth and Sports, 2010). Payung Island status as MPA, provide additional functionality to support the area surrounding waters. Almost of total area in Payung island is mangrove which has the biologically benefit that is as spawning and breeding grounds for fish, crabs, clams and shrimp. While ecologically, allows the region of Payung Island to participate in the control of $\mathrm{CO}_{2}$ because vegetated system i.e. mangroves. Therefore, this study is actually an early stage to analyze the carbon status of coastal South Sumatra, which starts from the MPA region i.e. Payung Island. This study focuses on carbon status (as sink or source carbon) in coast waters around Payung Island. Similar research never been done before, previous research which taken place in Payung Island was only checked carbon status in mangroves sediment. 


\section{Materials and Methods}

The study was conducted during June to August 2015 using 15 sampling points around the region Payung Island.(Figure 1 ). On the whole station the same research methods are needed, i.e. surface water sampling, measurement of air $\mathrm{CO}_{2}$ levels and measurements of hidrooceanography factors $(\mathrm{pH}$, temperature, salinity, DO). Procedures and the treatment of water samples carried out in accordance with Dickson et al. (2007), which samples were taken $500 \mathrm{ml}$ of water and immediately added $\mathrm{HgCl}_{2}$. The samples were then stored in a coolbox that has been filled with ice cubes and taken to the laboratory for analysis of dissolved inorganic carbon (DIC) and total alkalinity (TA). Measurement of $\mathrm{CO}_{2}$ concentration in the air is done by using Lutron $\mathrm{CO}_{2}$ meter $\mathrm{GCH} 2108$, whereas hidrooceanography factors measured insitu. DIC and TA analysis was performed using the titration method is based on the principle of changes in $\mathrm{pH}$ by addition of $\mathrm{HCl}$ and $\mathrm{NaOH}$ (Giggenbach \& Goguel, 1989). $\mathrm{pCO}_{2}$ calculation of performed using software CO2Calc (Rustam et al., 2014). Carbon sink and source status is determined by the equation (Rustam et al., 2014):

$$
\Delta \mathrm{pCO}_{2}=\mathrm{pCO}_{2 \text { seawater }}-\mathrm{pCO}_{\text {2atmospher }}
$$

The waters will act as a carbon source, if the calculation results show positive values $\mathrm{pCO}_{2}$ water is greater than atmospheric $\mathrm{pCO}_{2}$. Meanwhile, acts as a sink when the calculation result is negative.

\section{Results and Discussion}

Distribution of salinity in Payung Island waters were shown in Figure 2. Pattern of salinity in Payung island were higher toward the sea, with ranged between 0,0308-4,9747 PSU. Those pattern was influenced by mineral, organic matter, and sediment wich are brought to the estuary from river flow. When tides come from the sea, another organic matter from open sea brought to the estuary, increase the amount of organic matter content and affecting the level of salinity.

Distribution of Dissolved Inorganic Carbon (DIC) and partial pressure of carbon dioxide $\left(\mathrm{pCO}_{2}\right)$ in Payung Island were shown in Figure 3. DIC in surface waters of Payung Island ranged between 144,691080,91 $\mu \mathrm{mol} . \mathrm{kg}^{-1}$ (Figure 3). The highest DIC content was in station 2.3 which is an area of Musi River and the lowest DIC was in station 3.3 which is located closest the sea. Those ranges were larger than range which were found in Donan Estuary

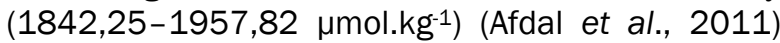
and in Pari Island, (1689,79-2065,97 $\left.\mu \mathrm{mol} . \mathrm{kg}^{-1}\right)$ (Rustam et al., 2014), but lower than DIC which found in Beras Basah Waters, Bontang City

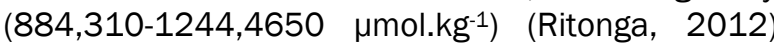
and Banten Bay (1329,87-1605,16 umol.kg-1) $^{-1}$ (Ramawijaya et al., 2012).

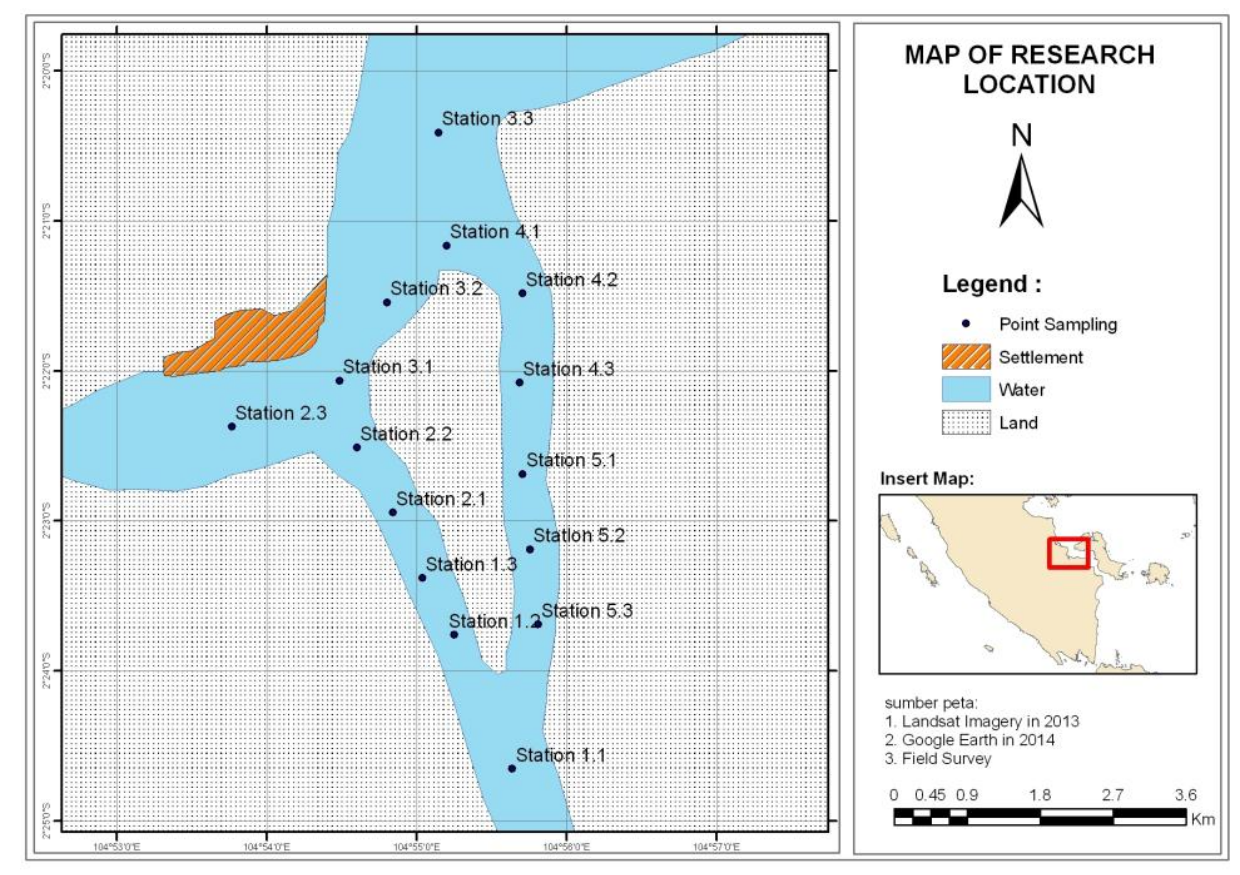

Figure 1. Location of Research 


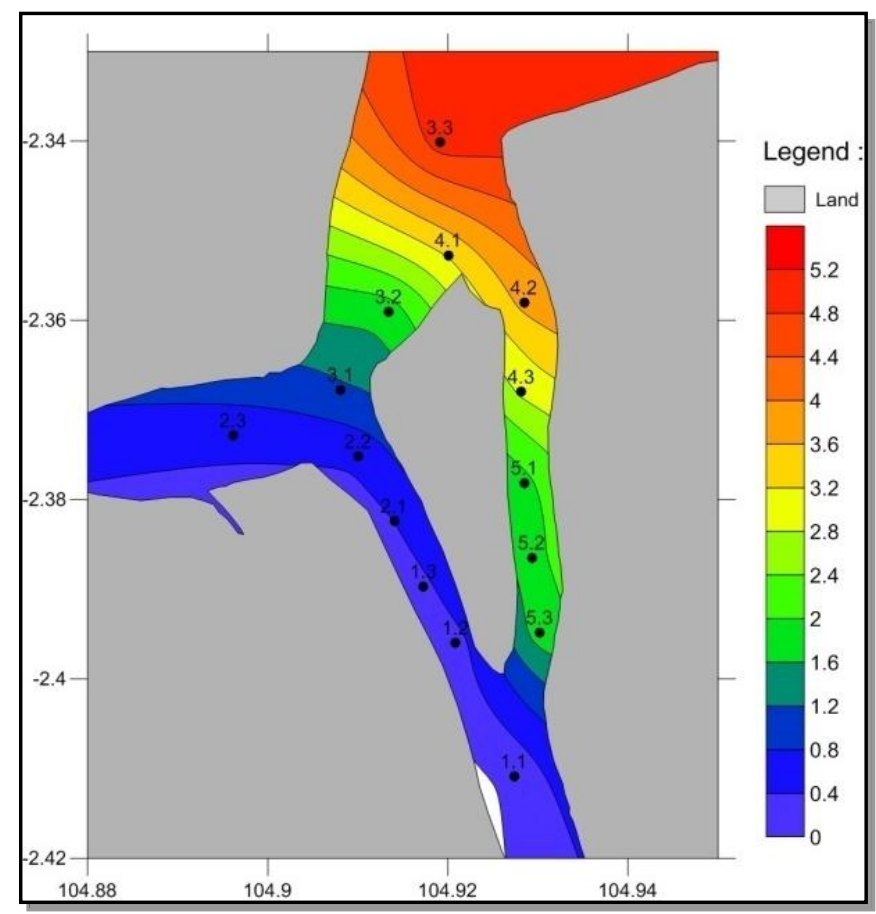

Figure 2. Distribution of salinity in Payung Island waters

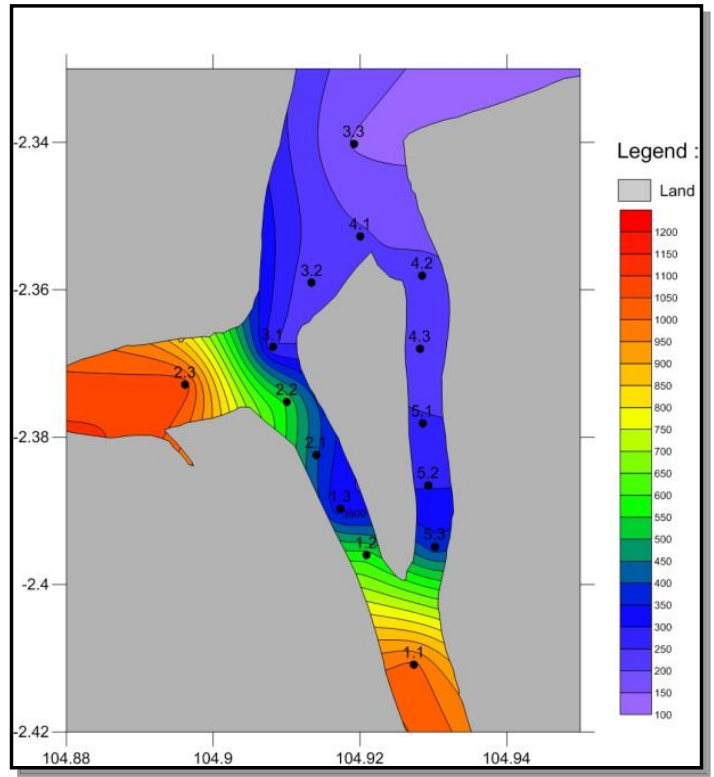

(a)



(b)

Figure 3 (a). Distribution DIC ( $\mu$ mol.kg-1) Payung Island waters; (b). Distribution $\mathrm{pCO}_{2}(\mu a t m)$ Payung Island waters

While $\mathrm{pCO}_{2}$ were obtained from the calculation of software $\mathrm{CO}_{2} \mathrm{Calc}$ using data value of $\mathrm{pH}$, DIC, total alkalinity, and environmental parameters such as salinity, temperature, nutrients (phosphate and silicate) and depth (Robbins, et al., 2010). $\mathrm{pCO}_{2}$ in Payung Island ranged from 63,0971601,322 ratm. The value of $\mathrm{pCO}_{2}$ in Payung Island was also higher than in Donan estuary $(1018,53-$ 1152,52 uatm) (Afdal et al., 2011) and Pari Island,

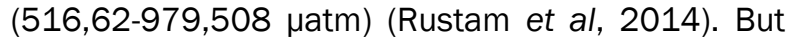

generally, those ranged still within the range $\mathrm{pCO}_{2}$ in estuaries globally in waters around the world which is 350-10.000 patm (Joesoef et al., 2015). The highest pCO2 was found in station 1.3 which located is near the Telang river, while the lowest $\mathrm{pCO}_{2}$ in Payung Island waters located in statiun 4.1 which is the widest part of the river's mouth prior to the open sea. In those area, presumably a change of the mass of water between fresh water at low tide and sea water at the tide very fast, so leaching of organic 
materials takes place in a short time and affect the $\mathrm{pCO}_{2}$. This was confirmed by Joesoef et al (2015) where the great estuary or bay with rapid freshwater transit time will have lower $\mathrm{pCO}_{2}$ than small estuary.

$\mathrm{DIC}$ and $\mathrm{pCO}_{2}$ in general has wide range and similar distribution pattern, which is high in the area of the mouth of the river and continues to drop as it is located towards the sea. It has related with the location of Payung Island which is in the middle of the mouth of two big major rivers in South Sumatera (Musi River in station 2.3 and Telang River in station 1.1). The two major rivers have a lot of activities in the upstream of which contribute to the carbon content in the flow of the river. Similar case was found by Nasprianto et al. (2016) in which one source of carbon in the waters originating from land. They also explained that anthropogenic activities such as irrigation, wetland disturbance and agriculture, can play a role as one of the carbon input to the river (Bauer et al., 2013).

This is also explained that the high $\mathrm{CO}_{2}$ in the river area was caused by the input from the area around the ground (Barth and Veizer, 1999; Jones and Mulholland, 1998), including wetlands (Hamilton et al., 1995), tidal swamp (Cai et al., 1999) and urban areas (Jarvie, et al., 1997). Liu et al. (2014) also confirmed that DIC decrease seaward with increasing salinity as in the present work (Figure 4). DIC distribution pattern is also obtained in the measurement DIC in Estuarine Donan, Cilacap (Afdal et al., 2011) and China Changjiang Estuaries (Zai et al., 2007).

The status of the Payung Island waters as a carbon sink or source were obtained from the calculation between $\mathrm{pCO}_{2}$ in waters and $\mathrm{pCO}_{2}$ in atmosphere and expressed by $\Delta \mathrm{pCO} 2$ ( $\mu$ atm) was shown in Figure 5. A water regarded to be a source when the value of positive and in the flow of water into the air/atmosphere. Meanwhile, when the value is negative, then the waters act as carbon sink. Seen from Figure 5, the waters around the Payung Island generally acts as a carbon source in station near the rivers (i.e. station 1.1, 1.2, 2.1, 2.3, 5.1, and 5.2). While in station towards the sea acts as carbon sink (i.e. station 1.3, 2.2, 3.1, 3.2, 3.3, 4.1, 4.2, 4.3 and

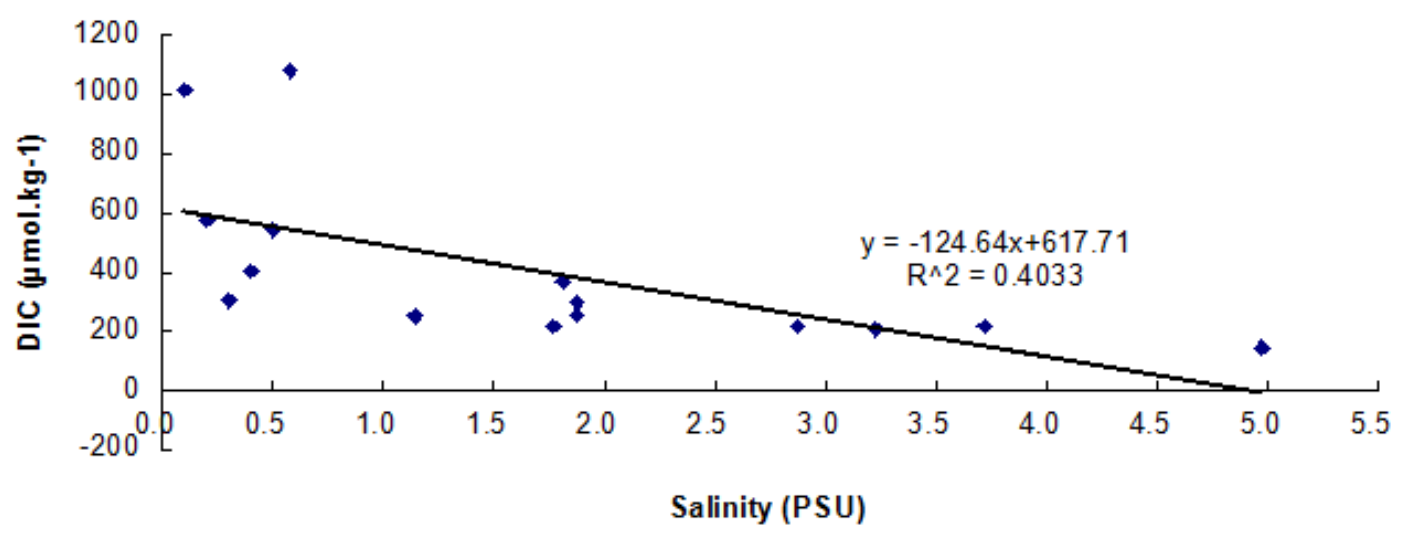

Figure 4. Regression between DIC and salinity in Payung Island waters



Station

Figure 5. The status of Payung Island waters as a carbon sink or source 
5.3). This indicates that the Musi and Telang River, are contributor of carbon. This is presumably because the sewage which is the result of human activities upstream role in increasing carbon waters. The rivers in the tropics in general are a contributor to carbon around $60 \%$ from total carbon, both organic and inorganic from the continent towards the open water (Bouillon \& Connolly, 2009). However, the presence of carbon in coastal areas being exchanged directly or indirectly and eventually stored in blue carbon mechanism (Rustam et al., 2014).

\section{Conclusion}

From the result of research, Payung Island waters generally act as a carbon sink in area towards the sea but in the territorial waters adjacent to the river as a source of carbon.

\section{Acknowledgment}

This study funded by Hibah Penelitian Unggulan Kompetitif Universitas Sriwijaya No. 215/UN9.3.1/LT/2015. Authors also wish to thank Yulianto Suteja and Azrinah Ulfah for help. Thanks also to two reviewers who gave valuable suggestions in improving this manuscript

\section{References}

Afdal, P.L.M.G. \& Noerjito, D.R. 2011. Fluks Karbon Dioksida, Hubungannya dengan Produktifitas Primer Fitoplankton di Perairan Estuari Donan. Oseanologi dan Limnologi di Indonesia, 37:323-337

Barth, J.A.C., \& Veizer, J., 1999. Carbon cycle in St. Lawrence aquatic ecosystems at Cornwall (Ontario), Canada: Seasonal and Spatial Variations. Chem. Geol., 159:107-128. doi: 10.1016/S0009-2541(99)00036-4

Bauer, J.E., Cai, W.J., Raymond, P.A., Bianchi, T.S., Hopkinson, C.S. \& Regnier, P.A.G. 2013. The Changing Carbon Cycle of The Coastal Ocean. [Abstrack]. Nature, 504:61-70. doi: 10.1038 /nature12857

Borges, A.V., 2005. Do we have enough pieces of the jigsaw to integrate $\mathrm{CO} 2$ fluxes in the coastal ocean?. Estuaries, 28(1):3-27

Borges, A.V., Delille, B. \& Frankignoulle, M., 2005. Budgeting sinks and sources of $\mathrm{CO} 2$ in the coastal ocean: Diversity of ecosystems counts.
Geophys. Res. Lett., 32(14). doi: 10.1029/2005GL023053

Bouillon, S. \& Connoly, R.M. 2009. Carbon exchange among tropical coastal ecosystems. Chapter 3. In: Nagelkerken, I (ed.). Ecological connectivity among tropical coastal ecosystems. Springer. Netherland

Cai, W.J., Pomery, L.R., Moran, M.A. \& Wang, Y. 1999. Oxygen and Carbon Dioxide Mass Balance for The Estuarine-Intertidal Marsh Complex of Five Rivers in The Southeastern U.S. 639. Limnol. Oceanogr., 44(3):639-649. doi: 10.4319/lo.1999.44.3.0639

Chen, C.T.A. \& Borges, A.V. 2009. Reconciling views on carbon cycling in the coastal ocean: Continental shleves as sinks and near-shore ecosystem as sources of atmospheric $\mathrm{CO} 2$. Deep-Sea Res II, 56:578-590. doi: 10.1016/j.dsr2.2009.01.001

Dickson, A.G., Sabine, C.L. \& Christian, J.R. (Eds). 2007. Guide to Best Practice for Ocean CO2 Measurements. PICES Special Publication 3, $191 p$

Giggenbach, W.F \& Goguel, R.L. 1989. Collection and Analysis of Geothermal and Volcanic Water and Gas Discharges. Report No. CD 2401, 4th edition. Chemistry Division, Department of Scientific and Industrial Research. Peton, New Zealand

Hamilton, S.K., Sippel, S.J. \& Melack, J.M. 1995. Oxygen Depletion and Carbon Dioxide and Methane Production in Waters of the Pantanal Wetland of Brazil. Biogeochem., 30(2):115-141

IPCC. 2001. The carbon cycle and atmospheric carbon dioxida. The Scientific Basis In Climate change 2001:185-237.

Jarvie, H.P., Neal, C., Leach, D.V., Ryland, G.P., House, W.A. \& Robson, A.J. 1997. Major Ion Concentrations and The Inorganic Carbon Chemistry of The Humber Rivers. Sci. of The Total Environment, 194-195:285-302. doi: 10.1016/S0048-9697(96)05371-5

Joesoef, A., Huang, W.J., Gao, Y. \& Cai, W.J. 2015. Air-water fluxes and sources of carbon dioxide in the Delaware Estuary: spatial and seasonal variability. Biogeosci., 12:6085-6101. doi: 10.5194/bg-12-6085-2015

Jones, J.B. \& Mulholland, P.J. 1998. Carbon Dioxide Variation in a Hardwood Forest Stream: An 
Integrative Measure of Whole Catchment Soil Respiration. Ecosystem. 1:183-196. doi: 10.10 07/s100219900014

Liu, Z., Zhang, L., Chai, W.J., Wang, L., Xue, M. \& Zhang, X. 2014. Removal of dissolved inorganic carbon in the Yellow River Estuary. Limnol. Oceanogr., 59(2):413-426. doi: 10.4319/ lo.2014.59.2.0413

Nasprianto, Mantiri, D.M.H., Kepel, T.L., Ati, R.N.A. \& Hutahean, A. 2016. Distribusi Karbon di Beberapa Perairan Sulawesi Utara. J. Manusia Dan Lingkungan, 23(1):34-41

Ramawijaya, Rosidah, Awaludin, M.Y. \& Pranowo, W.S. 2012. Variabilitas Parameter Oseanografi dan Karbon Laut di Teluk Banten. J. Perikanan dan Kelautan, 3 (3): 339-346

Ritonga, I.R. 2012. Distribusi Karbon Anorganik Dan Fluks $\mathrm{CO}_{2}$ Di Perairan Beras Basah, Kota Bontang. Lingkungan Tropis, 6(2):149-158. doi: 10.14499/jml.v23i1.609

Robbin, L.L., Hansen, M.E., Kleypas, J.A \& Meylan, S.C. 2010. A User-Friendly Seawater Carbon
Calculator for Windows, Mac OSX and iOS (iPhone). Florida Shelf Ecosystems Response to Climate Change Project. U.S Geological Survey, Reston, Virginia. http://pubs.usgs.gov/of/2010 /1280/

Rustam, A., Bengen, D.G., Arifin, Z. \& Gaol, J.L. 2014. Dinamika Dissolved Inorganic Carbon (DIC) Di Ekosistem Lamun Pulau Pari. J. Segara 10(1):31-41. doi: 10.15578/segara.v10i1.13

Takahashi, T., Sutherland, S.C., Sweeney, C., Poisson, A., Metzl, N., Tilbrook, B., Bates, N., Wanninkhof, R., Feely, R.A., Sabine, C., Olafsson, J. \& Nojiri, Y. 2002. Global sea-air CO2 flux based on climatological surface ocean pC02, andseasonal biological and temperature effects. Deep-Sea Res II, 49:1601-1622. doi: 10.1016/S0967-0645(02)00003-6

Zai, W.D., Dai. M. \& Guo, X. 2007. Carbonate System and $\mathrm{CO}_{2}$ Degassing Fluxes in The Inner Estuary of Changjiang (Yangtze) River, China. Marine Chem. 107(3):342-356. doi: 10.1016/ j.marchem.2007.02.011 